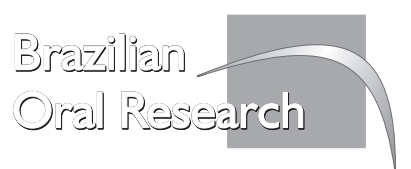

PUBLISHING COMISSION

Scientific Editor

Esther Goldenberg Birman

E-mail: egbirman@usp.br

Assistant Editors

Célia Regina M. D. Rodrigues

Célio Percinoto

José Luiz Lage-Marques

Sigmar de Mello Rode

Editorial Board

Acta Odontológica Latinoamericana (ARGENTINA)

Altair Del Bel Cury (FOP-UNICAMP)

Antonio Muench (Instituição)

Antonio Olavo Cardoso Jorge (FOSJC-UNESP)

Arlete E. Cury (FCF-USP)

ASDC Journal of Dentistry for Children (USA)

Bruno König (ICB-USP)

Christopher H. Fox (USA)

Claudete R. Paula (ICB-USP)

Crispian Scully (GREAT BRITAIN)

David Williams (ENGLAND)

Elza Manae Mamizuka (FCF-USP)

European Journal of Oral Science (SWEDEN)

Flavio Fava de Moraes (ICB-USP)

Frab Norberto Boscolo (FOP-UNICAMP)

Ii-Sei Watanabe (ICB-USP)

Ilana Eli (ISRAEL)

Isabel Yoko Ito (FCFRP-USP)

Jaime Aparecido Cury (FOP-UNICAMP)

Jayro Guimarães Junior (FO-USP)

Jeroen Kroon (SOUTH AFRICA)

João Gualberto Cerqueira Luz (FO-USP)

João Humberto Antoniazzi (FO-USP)

Luiz Carlos Pardini (FORP-USP)

Marcelo Gusmão Paraiso Cavalcanti (FO-USP)

Marcia P. A. Mayer (ICB-USP)

Maria Ercilia de Araujo (FO-USP)

Maria Regina Sposto (FOA-UNESP

Mariano Sanz (SPAIN)

Mario Fernando Goes (FOP-UNICAMP)

Mário Júlio Avila Campos (ICB-USP)

Marisa Semprini (FORP-USP)

Mônica Andrade Lotufo (FO-USP)

Nilza Pereira da Costa (PUC-RS)

Oral Disease (UNITED KINGDOM)

Orlando Ayrton de Toledo (UNB)

Osley Paes de Almeida (FOP-UNICAMP)

Paulo Capel Narvai (FSP-USP)

Pedro Luis Rosalen (FOP-UNICAMP)

Ricardo Martins Oliveira-Filho (ICB-USP)

Richard Ellen (CANADA)

Rosa Helena Miranda Grande (FO-USP)

Salete M. B. Cândido (FOA-UNESP)

Stephen Bayne (USA)

Stephen J. Challacombe (UNITED KINGDOM)

Vânia Célia V. Siqueira (FOP-UNICAMP)

Yupin Songpaisan (THAILAND)

The Editorial Board is composed of over 80 ad hoc

assistants, who are specialized in dentistry and

related areas.

Bibliographic Standardization

Lúcia Maria S. V. Costa Ramos

INDEXING

The Brazilian Oral Research is indexed in:

Base de Dados LILACS: 1991- ; Bibliografia

Brasileira de Odontologia (BBO): 1987-; Biological

Abstract: 1988- ; Index Medicus: 1997- ; Index

to Dental Literature: 1987- ; MEDLARS: 1997- ;

Medline: 1988- ; PubMed: 1997- ; The Serials

Directory: 1988- ; Ulrich's: 1988-

SUBSCRIPTIONS

SBPqO members: R $\$ 60.00$; $\mathrm{SBPqO}$ non-members: R $\$ 150.00$; Institutional: $R \$ 200.00$; Abroad:

US\$80.00

Phone/Fax number: (55-11) 3091-7855. Site: www.

sbpqo.org.br

ADDRESS FOR CORRESPONDENCE

Brazilian Oral Research

Av. Prof. Lineu Prestes, 2227

Cidade Universitária "Armando Salles de

Oliveira"

05508-900 - São Paulo - SP - Brasil

Phone number: (55-11) 3091-7810

E-mail: pob@edu.usp.br

EDITORIAL PRODUCTION

Ricardo Borges Costa
EDITORIAL

\section{Ethical aspects when using animals in research}

A ccording to the Helsinki Declaration, adopted by the $18^{\text {th }}$ World Medical Assembly in Helsinki, Finland (1964), the first item of the Basic Principles states that "Biomedical research involving human subjects must conform to generally accepted scientific principles and should be based on adequately performed laboratory and animal experimentation and on a thorough knowledge of the scientific literature".

The Declaration of Geneva of the World Medical Association links physicians with the principle: "The health of my patient will be my first consideration". My patient, in this case, is a HUMAN BEING, but my patient may also be considered a LABORATORY ANIMAL.

Mandatory disciplines that discuss the care of animals used in experimentation have been created in our university. These disciplines are taught by researchers, veterinarians and animal care professionals.

The Brazilian College of Animal Experimentation (COBEA), affiliated with the International Council for Laboratory Animal Science (ICLAS) promotes the ethical care of laboratory animals used in research in our country. The first article of the Ethical Principles of the COBEA states that "All people involved in biological research must understand that laboratory animals have sensibility, memory and experience inescapable pain".

Various Brazilian researchers are not aware of this article and submit so-called "scientific manuscripts" to journals. These manuscripts contain reports of cruelty towards animals. Research without ethics cannot be considered serious research. Cruelty is the opposite of research. It is hideous, and can be compared to the atrocities committed at nazi concentration camps during World War II.

Ninety-five percent of the manuscripts submitted to the Acta Cirúrgica Brasileira - journal where I work as Chief Editor - involve research with laboratory animals. Manuscripts which are not in accordance with the ethical principles of animal experimentation are often submitted, but these unethical manuscripts are not accepted by the journal. They are returned to the author with the recommendations of the COBEA.

The Teaching Commission of the COBEA developed and published the revised and expanded $2^{\text {nd }}$ edition of the manual for animal care professionals in 1996. Chapter 2 of this manual covers "Ethics, well-being and regulations regarding animal use in research".

It is necessary and even mandatory that Research Ethics Committees be created in every Institution where research is conducted. These committees must analyze protocols and also have teaching responsibilities. 
People who use animals in research must be educated and aware of the ethical principles involving animal experimentation. The number of animals used should be reduced to the minimum possible, and animal pain, suffering or stress should be avoided. In England, concern regarding the use of animals in research has been voiced since 1876 .

In 1988, the National Council of Health $(\mathrm{NCH})$ approved the first regulations regarding ethics in research with human beings in Brazil. Soon after, a text which became NCH Resolution n. 196 was written. This Resolution led to the creation of the National Research Ethics Committee (CONEP), affiliated with the National Health Committee. CONEP regulates the protection of human beings involved in research. But where is the Committee that will protect the animals involved in research?

The Federal Law n. 6638 (dated May, 1979) regulates vivisection in the teaching of science, as well as other issues. However, it has not yet been regulated and implemented. Another bill to be approved by Congress, n. 1153/95, may restrict research using animals. This situation is worrying. Laws must warrant the proper care and use of animals in research, but we must be careful not to approve radical laws that may jeopardize our scientific and technological development.

The control of ethical issues involving animal experimentation can and should be exerted by journals when receiving the manuscripts submitted.

The instructions for authors of our journal - Acta Cirúrgica Brasileira - include a paragraph stating that ethical principles regarding the use of animals in research must be followed. But it does not suffice. We are currently requiring a copy of the letter of approval by the Research Ethics Committee of each institution where the study was conducted. In addition, each article must be approved by two different referees, who also analyze the ethical aspects regarding animal experimentation.

A study carried out at the School of Medicine of Botucatu, São Paulo State University, analyzed the instructions for authors of 139 Brazilian journals. They concluded that the majority of the journals $(79.1 \%)$ did not mention ethical issues. Among the 29 journals that mentioned ethical issues, only one required a copy of the Research Ethics Committee letter of approval.

Let's hope that the problem we face regarding animal experimentation be duly addressed by editors.

Saul Goldenberg Chief Editor, Acta Cirúrgica Brasileira.

\section{Atenção autores!}

O contato entre editora e autores durante as fases de revisão e editoração é imprescindivel ao processo de publicação de seu artigo. Qualquer mudança de endereço, telefone ou e-mail deve ser imediatamente comunicada à Revista, sob risco de seu artigo não ser publicado.

Ressaltamos que a observância às "Instruções aos autores" (pág. 77-80) para a submissão dos artigos diminui a necessidade do contato e agiliza o processo editorial.

\section{Colabore!}

